Jurnal Abdimas Berdaya : Jurnal Pembelajaran, Pemberdayaan dan Pengabdian Masyarakat Volume 4 Nomor 02 Tahun 2021

P-ISSN: $2685-1563$ e-ISSN: 2720 - 9768

\title{
Peningkatan Entrepreneurial Marketing Pada UMKM Di Wilayah Desa Seduri Kecamatan Balongbendo Sidoarjo
}

\section{Increasing Entrepreneurial Marketing in MSME in the Seduri Village Area, Balongbendo District, Sidoarjo}

\author{
Ratna Ekasari' $^{1)}$, Rezki Aulia ${ }^{2)}$, Mohamad Fadli Safrifudin ${ }^{3)}$, Nur Khomariyah ${ }^{4)}$ \\ 1,2,3,4 Universitas Maarif Hasyim Latif Sidoarjo \\ e-mail: ratna_ekasari@dosen.umaha.ac.id
}

\begin{abstract}
Abstrak: Pengabdian ini bertujuan untuk meningkatkan strategi bisnis serta inovasi dalam mempertahankan Usaha Mikro Kecil Menengah yang terdampak oleh pandemi covid 19 pada wilayah Desa Seduri Kecamatan Balongbendo Sidoarjo. Pada strategi bisnis dan Inovasi ini yang menjadi fokus peningkatan dalam Usaha Mikro Kecil Menengah adalah dengan melakukan pemasaran pada media sosial atau digital marketing, meningkatkan kualitas, serta menjaga pelayanan

Kata Kunci: Strategi Bisnis, Inovasi, UMKM, Pandemi Covid 19

Abstract: This service aims to improve business strategies and innovations in maintaining Micro, Small and Medium Enterprises affected by the COVID-19 pandemic in the Seduri Village area, Balongbendo District, Sidoarjo. In this business strategy and innovation, the focus of improvement in Micro, Small and Medium Enterprises is to do marketing on social media or digital marketing, improve quality, and maintain service.
\end{abstract}

Keywords: Business Strategy, Innovation, MSME, Covid 19 Pandemic

\section{A. Pendahuluan}

Pandemi merupakan sebuah epidemi yang telah menyebar ke berbagai benua dan Negara, umumnya menyerang banyak orang. Sementara epidemi sendiri adalah sebuah istilah yang telah digunakan untuk mengetahui peningkatan jumlah kasus penyakit secara tiba-tiba pada suatu populasi area tertentu. Istilah pandemi tidak digunakan untuk menunjukkan tingginya tingkat suatu penyakit, melainkan hanya memperlihatkan tingkat penyebarannya saja. Kasus pandemi Covid-19 ini menjadi yang pertama dan disebabkan oleh virus corona yang telah ada sejak akhir tahun 2019.

Di Indonesia, Pandemi Covid-19 masih terjadi dan menyebabkan beberapa permasalahan dari berbagai sektor, di antaranya sektor kesehatan, sektor pendidikan, sektor sosial maupun sektor ekonomi. Dampak pandemi Covid- 19 yang paling dirasa sangat merugikan Indonesia salah satunya dalam sektor ekonomi. Dimana kegiatan perekonomian, merupakan aktivitas masyarakat dalam pemenuhan kebutuhan seharihari (Prudential, 2020).

Kegiatan perekonomian untuk masyarakat kelas menengah kebawah yakni UMKM juga menjadi hal yang sangat memprihatinkan. Karena UMKM merupakan kegiatan usaha berskala kecil yang mendorong pergerakan pembangunan dan 
perekonomian Indonesia. UMKM dapat mencakup berbagai bidang usaha. Misalnya dalam Bidang jasa yaitu UMKM Londry.

Menurut (Firmansyah, 2020) UMKM Londry merupakan sebuah usaha dalam bidang jasa. Bentuk jasa yang ditawarkan adalah mencucikan pakaian atau barangbarang lainnya yang umum digunakan oleh konsumen. Usaha londry bukan hanya tentang pakaian saja melainkan perlengkapan rumah yang terbuat dari kainyang bisa di terima oleh usaha laundry, termasuk sprei, sarung bantal, selimut, tirai, sajadah, taplak meja, tas, dan masih banyak lagi.

Namun selama pandemi Covid-19 yang telah di ulas sebelumnya mengakibatkan penurunan minat masyarakat terhadap permintaan jasa londry. Seperti yang di alami UMKM "One Clean Londry" di desa Seduri Kecamatan Balongbendo Kabupaten Sidoarjo. UMKM ini, berdiri sejak tahun 2016 dengan teknik promosi yang sederhana dengan membagikan selebaran kertas promosi usaha, plakat usaha dan dari mulut ke mulut. Sebelum pandemi, pendapatan UMKM “One Clean Londry" terbilang lancar karena wilayah usaha yang strategis dengan mayoritas masyarakat yang memiliki profesi dan kesibukan yang padat sehingga sangat membutuhkan jasa londry. Namun sejak penurunan permintaan jasa londry akibat pandemi Covid-19 dan belum dilakukannya perubahan strategi marketing mengakibatkan stag usaha yang di alami UMKM “One Clean Londry”.

Untuk itu perlu adanya peningkatan promosi/marketing dan inovasi- inovasi baru terhadap UMKM Londry. Dengan peggabungan evolusi Indutri 4.0 seperti digital marketing dengan strategi bisnis sangat diharapkan dapat mempertahankan UMKM londry di tengah pandemi Covid-19. Serta dapat mengembangkan Usaha londry sebagai UMKM yang menjanjikan dan membantu mengangkat prosentase UMKM Indonesia dengan penyerapan tenaga kerja dan pendapatan nasional yang tinggi.

Menurut Kotler dan Armstrong 2018:29 dalam (Ulfa \& Wijayangka, 2020), pemasaran sebagai proses dimana perusahaan melibatkan pelanggan, membangun hubungan pelanggan yang kuat, menciptakan hubungan pelanggan dan menciptakan nilai pelanggan untuk mendapatkan nilai dari pelanggan sebagai imbalan. Menurut Irum (2016:591) pemasaran adalah kegiatan yang dilakukan oleh beberapa pihak atau kumpulan orang (organisasi) yang dikordinir dengan baik yang disebut dengan produsen yang bertujuan menyalurkan barang maupun jasa kepada konsumen secara tepat sasaran serta dapat memuaskan konsumen dan juga menguntungkan pihak-pihak dari produsen tersebut.

Dari teori para ahli tersebut maka dapat disimpulkan bahwa pemasaran merupakan suatu kegiatan yang dilakukan oleh seorang pengusaha baik itu UMKM atau perusahaan dalam membangun suatu kepercayaan terhadap konsumen sehingga konsumen tersebut membeli produk atau jasa yang kita tawarkan sesuai dengan kebutuhan yang akan digunakan oleh konsumen.

Menurut Rangkuti (2013) berpendapat bahwa strategi merupakan rencana yang komprehensif yang digunakan perusahaan untuk mencapai semua tujuan yang 175 
ditetapkan berdasarkan misi yang ditentukan terlebih dahulu. Strategi merupakan suatu alat yang sangat penting untuk mencapai keunggulan bersaing dan diartikan pula sebagai suatu proses penentuan rencana perusahaan yang berfokus pada tujuan jangka panjang disertai penyusunan cara atau upaya agar tujuan tersebut dapat tercapai (Putri \& Effendi, 2015). Strategi memberi jawaban bagi pihak manajemen mengenai bagaimana cara mencapai tujuan perusahaan dan bagaimana caranya untuk mencapai misi organisasi dan visi strategis. Pembuatan strategi adalah tentang bagaimana mencari target-target, bagaimana bersaing dengan para kompetitor, bagaimana mencapai keunggulan bersaing yang berkepanjangan, bagaimana membuat visi strategis manajemen sebagai sebuah kenyataan bagi suatu perusahaan (Faruq \& Usman, 2016).

Menurut hasil pengamatan dan observasi pada pengabdian ini strategi bisnis ini adalah suatu rencana jangka panjang yang akan dilakukan oleh seorang pengusaha dalam melakukan perencanaan yang bertujuan untuk mencapai misi dan visi suatu perusahaan atau UMKM, Strategi tersebut dapat berupa bagaimana cara untuk mencapai target pasar, cara bersaing dengan kompetitor, cara keunggulan bersaing dalam jangka waktu yang panjang dengan membuat penyusunan rencana yang telah ditentukan untuk mencapai tujuan yang telah dibuat.

\section{B. Metode}

Kegiatan pengabdian ini dilaksanakan pada salah satu Usaha Mikro Kecil Menengah dalam bidang Jasa Cuci Pakaian dan sejenisnya (Laundry) yang terdampak oleh pandemi Covid 19 pada wilayah Desa Seduri Kecamatan Balongbendo Sidoarjo dengan melakukan pemilihan mintra sebagai target atau sasaran progam kegiatan pengabdian masyarakat.

Melalui pengamatan kondisi mitra, wawancara dan praktik pembaruan strategi bisnis dan inovasi sesuai tahap-tahap nya dengan perencanaan yang lebih matang dan terstruktur sehingga monitoring kepada pelaku usaha lebih maksimal. Pelatihan juga dilakukan terkait pengelolaan media sosial sebagai inovasi di dalam melakukan pemasaran dalam strategi bisnis guna menarik minat calon konsumen kepada mitra.

\section{Hasil dan Pembahasan}

UMKM merupakan kegiatan usaha berskala kecil yang mendorong pergerakan pembangunan dan perekonomian Indonesia. UMKM dapat mencakup berbagai bidang usaha. Misalnya dalam Bidang jasa yaitu UMKM Londry. Menurut (Firmansyah, 2020). UMKM Londry merupakan sebuah usaha dalam bidang jasa. Bentuk jasa yang ditawarkan adalah mencucikan pakaian atau barang-barang lainnya yang umum digunakan oleh konsumen.

Namun selama pandemi Covid-19 yang telah di ulas sebelumnya mengakibatkan penurunan minat masyarakat terhadap permintaan jasa londry. Seperti yang di alami UMKM "One Clean Londry" di desa Seduri Kecamatan Balongbendo Kabupaten Sidoarjo. Sebelum pandemi, pendapatan UMKM "One Clean Londry" terbilang lancar 
karena wilayah usaha yang strategis dengan mayoritas masyarakat yang memiliki profesi dan kesibukan yang padat sehingga sangat membutuhkan jasa londry. Namun sejak penurunan permintaan jasa londry akibat pandemi Covid-19 dan belum dilakukannya perubahan strategi marketing mengakibatkan stag usaha yang di alami UMKM “One Clean Londry”.

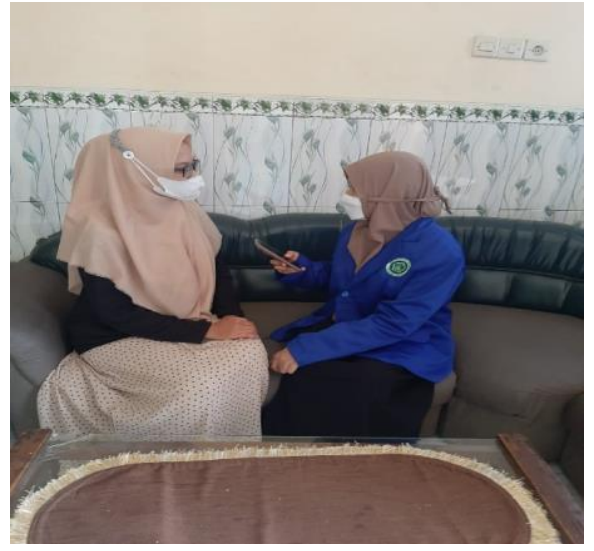

Gambar 4.1 Wawancara kepada pemilik UMKM One Clean Laundry

Untuk itu perlu adanya peningkatan promosi/marketing dan inovasi- inovasi baru terhadap UMKM Londry. Dengan peggabungan evolusi Indutri 4.0 seperti digital marketing dengan strategi bisnis sangat diharapkan dapat mempertahankan UMKM londry di tengah pandemi Covid-19.

1. Permasalahan Marketing

Permasalahan yang dialami oleh pelaku UMKM Laundry setelah diamati oleh peneliti adalah :

a. Akibat Pandemi Covid-19 terjadi stagnasi perekonomian di Indonesia misalnya UMKM dari berbagai bidang. Dalam UMKM “One Clean Londry" terjadinya keterbatasan akses dalam mengupayakan promosi usaha maupun kegiatan usaha menjadi terhenti akibat Pandemi ini.

b. Akibat pandemi Covid 19 masyarakat tidak dapat berinteraksi secara langsung dan bebas. Harus mengikuti protokol kesehatan sehingga strategi Marketing secara offline sangat tidak efisien.

2. Solusi Permasalahan

Solusi permasalahan yang dialami oleh pelaku UMKM Laundry setelah diamati oleh peneliti adalah :

a. Pandemi Covid-19 merupakan hal yang tidak bisa di hindari oleh semua lapisan masyarakat. Namun, stagnasi perekonomian harus tetap ditindak lanjuti dengan membangun strategi bisnis dan inovasi baru yang relevan dengan kondisi saat ini untuk dapat mempertahankan UMKM di Indonesia, termasuk UMKM "One Clean Londry".

b. Pandemi Covid-19 menuntut masyarakat dalam berinteraksi harus sesuai dengan protokol kesehatan sehingga dalam mempertahankan UMKM Londry dengan 
cari melakukan digital marketing sebagai promosi/penawaran jasa, Macammacam digital marketing (Bezimedi, 2018) di antaranya :

1) Website

2) Sosial Media

Langkah selanjutnya dalam mempertahankan UMKM Londry yaitu dengan melakukan perbaikan kualitas dan packaging Londry, diantaranya :

a. Kualitas Laundry

b. Packaging Produk

3. Diskusi Entreprenuer

Kemudian diskusi yang telah dilakukan Tim Pengabdian Masyarakat Bersama pemilik UMKM One Clean Laundry dalam hal Entreprenuer menghasilkan simpulan mengenai permasalahan atau kesulitan yang dihadapi UMKM ini dalam segi marketing. Sebagai Identitas UMKM maka perlu diciptakan logo usaha. Setelah logo dibuat maka solusi yang efektif dalam melakukan promosi layanan jasa Laundry ini dibedakan menjadi 2, yaitu secara offline maupun online.

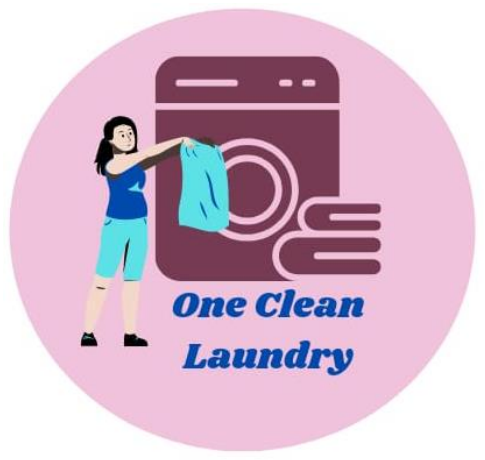

Gambar 4.2 Logo One Clean Laundry

Promosi offline tidak mengalami perubahan yaitu cukup dengan memasang banner di depan rumah/ tempat usaha, membagikan selebaran kertas promosi usaha (Leaflet), plakat usaha dan dari mulut ke mulut. Namun dalam mempromosikan Layanan jasa Laundry secara online untuk saat ini harus ditingkatkan sebab Pandemi Covid-19 menuntut masyarakat dalam berinteraksi harus sesuai dengan protokol kesehatan sehingga dalam mempertahankan UMKM Laundry dengan cari melakukan digital marketing sebagai promosi/penawaran jasa. Beberapa yang sudah diupayakan adalah Pemanfaatan media sosial seperti facebook, whatsapp dan Instagram merupakan digital marketing yang cukup popular dalam mempromosikan UMKM. Sehingga laundry juga bisa memanfaatkan social media tersebut sebagai salah satu metode promosi secara online dengan mencantumkan nama, alamat dan deskripsi usaha secara jelas sehingga menarik konsumen maupun pelanggan untuk menggunakan jasa laundry. 
Tabel 1. List Sosial Media One Clean Laundry

\begin{tabular}{|l|l|l|l|}
\hline No & Sosmed & $\begin{array}{l}\text { Nama } \\
\text { Sosmed }\end{array}$ & No hp/link \\
\hline & Whatsapp & $\begin{array}{l}\text { One Clean } \\
\text { Laundry }\end{array}$ & 085735585131 \\
\hline & Facebook & $\begin{array}{l}\text { One Clean } \\
\text { Laundry }\end{array}$ & $\begin{array}{l}\text { https://www.facebook.com/One-Clean- } \\
\text { Laundry-100912125661630 }\end{array}$ \\
\hline & Instagram & $\begin{array}{l}\text { Oneclean_- } \\
\text { Laundry }\end{array}$ & $\begin{array}{l}\text { https://instagram.com/oneclean_laundry?ut } \\
\text { m_medium=copy_link }\end{array}$ \\
\hline
\end{tabular}

4. Analisa Output

Terdapat perbedaan yang dirasakan oleh UMKM One Clean Laundry sebelum dan sesudah di dampingi dan didanai oleh Tim Pengabdian Masyarakat. Dapat dilihat pada tabel berikut ini :

a. Sebelum adanya pendampingan

1) Dari segi pemasaran tentu belum ada inovasi baru dan lebih condong pada pemasaran online

2) Pemasukan dana mengalami stagnasi dikarenakan pandemic

3) Kualitas layanan jasa terbilang biasa saja. Karena kurang wawasan

b. Setelah adanya pendampingan

1) Memiliki akun sosial media yang sangat memudahkan dalam pemasaran online dan mengenalkan layanan jasa laundry kepada konsumen

2) Dapat mempertahankan usaha karena menemukan trobosan baru melalui bidang marketingnya.

Sudah memiliki nota Laundry, dan mempertahankan layanan jasa Laundry agar tidak mengecewakan pelanggan dan ilmunya didapati melalui Tim Pengabdian Masyarakat dalam sesi diskusi Entreprenuer

\section{Simpulan}

Dari hasil kegiatan pengabdian masyarakat di Usaha Mikro Kecil Menengah yang terdampak oleh pandemi covid 19 pada wilayah Desa Seduri Kecamatan Balongbendo Sidoarjo. menunjukkan bahwa:

1. Meningkatnya pengetahuan mitra selaku pelaku Usaha mikro mengenai pentingnya peningkatan strategi bisnis serta inovasi di dalam melakukan pemasaran jasa yang di tawarkan kepada calon konsumen agar Usaha yang telah dikelola memiliki target pasar yang lebih luas.

2. Meningkatnya ketrampilan dalam pengelolaan digital marketing melalui media sosial sehingga dapat menjangkau target calon konsumen walaupun terdampak oleh adanya pandemi covid 19 .

3. Menambah wawasan kepada mitra selaku pelaku usaha tentang manfaat-manfaat strategi bisnis dan inovasi dalam menjalankan suatu UMKM agar dalam kondisi apapun usaha yang di jalankan dapat bertahan dan berkembang. 


\section{Daftar Rujukan}

Faruq, M. A., \& Usman, I. (2016). Penyusunan Strategi Bisnis Dan Strategi Operasi Usaha Kecil Dan Menengah Pada Perusahaan Konveksi Scissors Di Surabaya. Jurnal Manajemen Teori Dan Terapan| Journal of Theory and Applied Management, 7(3), 173-198. https://doi.org/10.20473/jmtt.v7i3.2710

Firmansyah, K. (2020). Cara sukses memulai bisnis laundry bagi pemula. prudential. (2020). Dampak Pandemi Covid-19.

Ulfa, N., \& Wijayangka, C. (2020). ANALISIS STRATEGI PEMASARAN UMKM DALAM MENGHADAPI ( STUDI PADA UMKM DIBIDANG FASHION DI KOTA BANDUNG ). 7(2), 3569-3576. 